\section{A Portable Small-Stage Photoelectric Planimeter for Leaf Area Measurements ${ }^{1}$}

\section{MARTYN M. CALDWELL AND RUSSELL T. MOORE ${ }^{2}$}

Associate Professor and Graduate Research Assistant, Dept. of Range Science and the Ecology Center, Utah State University, Logan, Utah.

\section{Highlight}

A small and inexpensive photoelectric planimeter is described. This planimeter is particularly suited for the precise determination of leaf area for many western range species.

The importance of leaf area determinations in the plant sciences has stimulated the use of a great variety of techniques for measurement of leaf area (Marshall, 1968). Light interception techniques have been used most extensively for fast yet accurate determinations of leaf area. A large number of such photoelectric planimeters have been devised (Marshall, 1968).

Most photoelectric planimeters follow the same basic design. Leaves are held in a horizontal position on a stage and illuminated from above with a defuse light source. The amount of light intercepted by these leaves is measured by a photoelectric sensor located below the stage. The components of such a devise are housed in a light-proof enclosure. Since most planimeters have been designed to ac-

${ }^{1}$ Journal Paper No. 1084 of the Utah Agricultural Experiment Station. Received September 18, 1970.

2 The assistance of Mr. Lee Camp in the construction and testing of the planimeter is gratefully acknowledged. commodate large leaves, a large evenlyilluminated stage is paramount. To achieve this, it has been necessary to use substantial distances between the light source, the stage and the sensor (Donovan et al., 1958); collimating and condensing lenses (Miller et al., 1956; Davis et al., 1966); or an optical cone (Kramer, 1937). These modifications have resulted in extremely large and complex planimeters which are often expensive and limited to laboratory use. Small portable photoelectric planimeters have been devised, but these have not been refined to the point where errors can be reduced to an acceptable level (Voisey and Kloek, 1964).

Desert range species are particularly suited for use in a small-stage photoelectric planimeter. A large number of these small leaves can be conveniently placed on a rather small stage and most species have leaves which are completely opaque. We describe here a small stage, inexpensive, portable and precise photoelectric planimeter, which is particularly suited for western range species.

\section{Methods and Materials}

Construct a small light-tight housing $(30 \times 30 \times 60 \mathrm{~cm})$ of a suitable material such as $6 \mathrm{~mm}(1 / 4$ inch) plywood with a small access door (Fig. 1). Paint the inside of this housing with a mat black paint and provide the access door with a rubber light-tight seal. A small 25 watt a-c bulb provides an excellent source of illumination if line power is available. A small 6 or 12 d-c automotive bulb could also be employed when line current is not available. Mount this lamp on a small plate and use a series of bolts with wing nuts or a similar mounting scheme to adjust the height of the plate. Because of the low amount of heat produced by such a bulb, no ventilation is required in the housing as is usually needed in most other photoelectric planimeters (Davis et al., 1966; Kramer, 1937; Miller et al., 1956). The illumination sensor used in this particular planimeter is a $4.9 \mathrm{~cm}$ (1.9 inches) diam. photovoltaic cell (Model HR-1247, Centralab Instruments Co., El Monte, California). The output from this photovoltaic cell is measured with a microammeter. The stage is located immediately above the light sensor and consists of a piece of normal window glass painted with black paint except for a $4.9 \mathrm{~cm}$ diam. area immediately above the photocell. Spread the leaves on this $4.9 \mathrm{~cm}$ diam. stage and cover the leaves with a piece of frosted glass to hold the leaves flat and to insure an even illumination field. If necessary, a series of screen filters can be placed between the stage and the lamp to reduce and defuse the light. This photoelectric planimeter can be constructed for less than $\$ 100$.

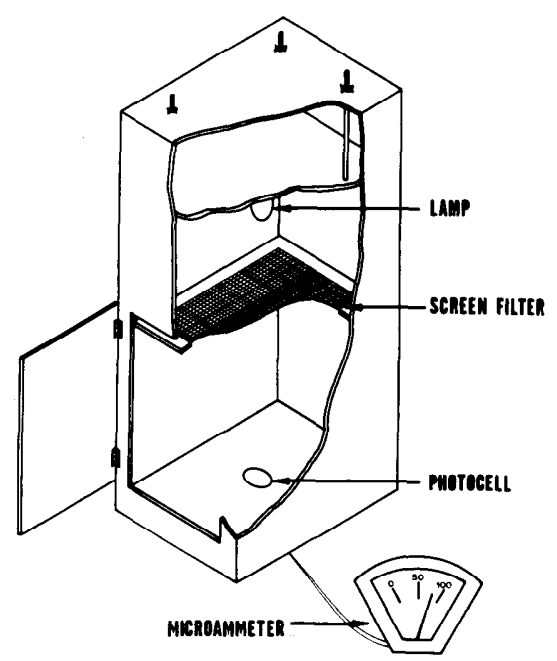

Fig. 1. Cut-away diagram of photoelectric planimeter. 


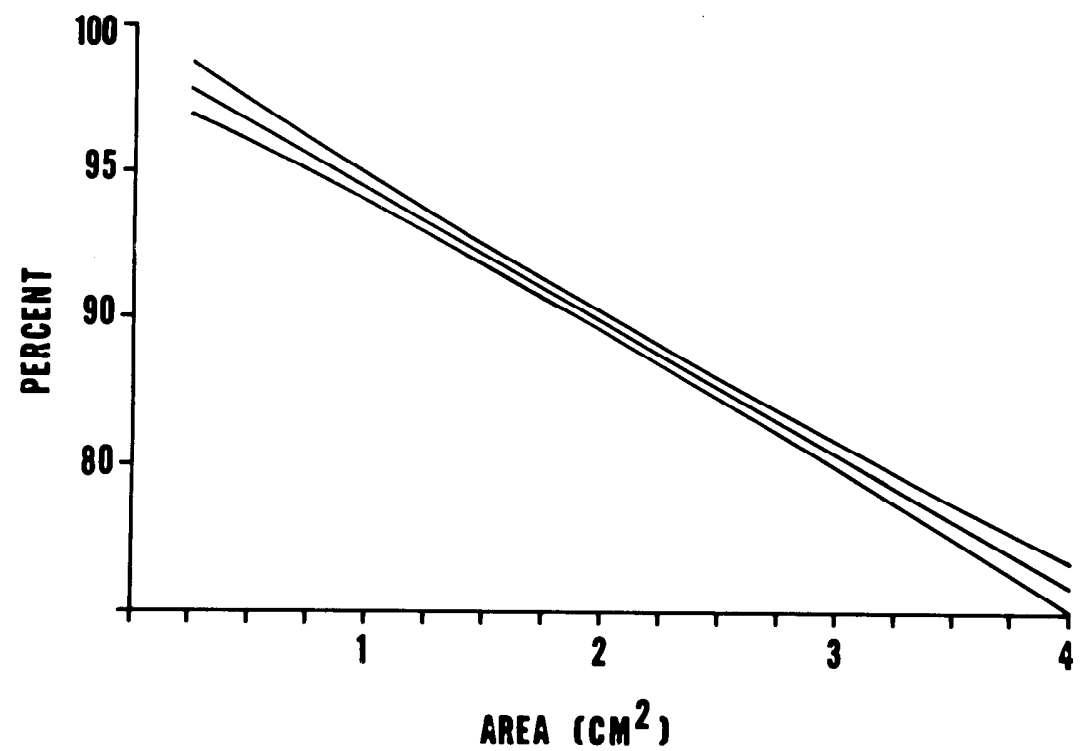

FIG. 2. Linear regression of percent full scalc microammeter reading and leaf area. The $95 \%$ confidence bands are also shown $-\mathrm{r}^{2}=.987$.

\section{Results and Discussion}

Since the height of the light bulb above the stage is variable, adjust the instrument to indicate a full scale microammeter reading when no leaves are on the stage. Check this before and after each leaf sample is read. This will compensate for any changes in bulb output or sensitivity of the photoelectric sensor caused by changes in temperature. Place the leaves on the stage and cover with the frosted glass for a photocell reading.

We calibrated this planimeter with small pieces of opaque paper of known area. A linear regression from these data possesses a coefficient of determination, $r^{2}$, of 0.987 . The regression equation and the $95 \%$ probability confidence bands for this regression are plotted in Figure 2. These confidence bands suggest the limits of error for prediction of leaf area based on the regression relationship. The area of a leaf sample which yields approximately $90 \%$ of full scale reading on the microammeter can be predicted within \pm $7 \mathrm{~mm}^{2}$ or $\pm 2 \%$ with $95 \%$ probability. For small leaves, this represents a high degree of accuracy.

This portable planimeter has been used extensively for determination of leaf area for a number of cold desert range shrubs such as shadscale (Atriplex confertifolia), and winterfat (Eurotia lanata). In addition, the instru- ment has been used successfully for leaf area determination of forage samples from fistulated sheep.

This small-stage planimeter is ideally suited for field or laboratory measurements of small leaves such as from desert range plants. For larger leaves, especially those which are not completely opaque, a large stage air-flow planimeter would appear preferable (Jenkins, 1959; Mayland, 1969).

\section{Literature Cited}

Davis, R. G., G. M. Roberson, W. C. Johnson, AND A. F. Wiese. 1966. A modified optical planimeter for measuring leaf area. Agron. J. 58: 106-107.

Donovan, L. S., A. I. Magee, and W. KALBFLEISCH. 1958. A photoelectric device for measurement of leaf areas. Can. J. Plant Sci. 38:490-494.

Jenkins, H. V. 1959. An air-flow planimeter for measuring the area of detached leaves. Plant Physiol. 34: 532-536.

Kramer, P. J. 1937. An improved photoelectric device for measuring leaf areas. Am. J. Bot. 24:375-376.

Marshall, J. K. 1968. Methods for leaf area measurement of large and small leaf samples. Photosynthetica 2:41-47.

MaYland, H. F. 1969. Air-flow planimeter for measuring detached leaf area. J. Range Manage. 22:357-359.

Miller, E. F., C. A. Shadbolt, and L. G. Holm. 1956. Use of an optical planimeter for measuring leaf area. Plant Physiol. 31:484-486.

Voisey, P. W., ANd M. Kloek. 1964. A portable leaf area measuring instrument. Can. J. Plant Sci. 44: 389391. 